\title{
CREATIVIDAD E INNOVACIÓN GRASTRONÓMICA
}

Por: Nicolas Sabogal.

La creatividad es una forma de desarrollar la identidad del ser humano, donde su objetivo es demostrar la evolución de algo ya existente. Para muchos la creatividad solo es una forma de ser "novedoso", a partir de la expresión de perspectivas distintas de algo ya establecido, de forma empírica y arbitraria; pero, lo que en realidad respecta a un acto creativo es el echo de innovar respecto a elementos ya establecidos y usados de acuerdo a corrientes científicas, sociales y culturales. Hay cabida a pensamientos escépticos que obligan al creador-innovador a explorar diferentes campos para llegar a su producto pensado.

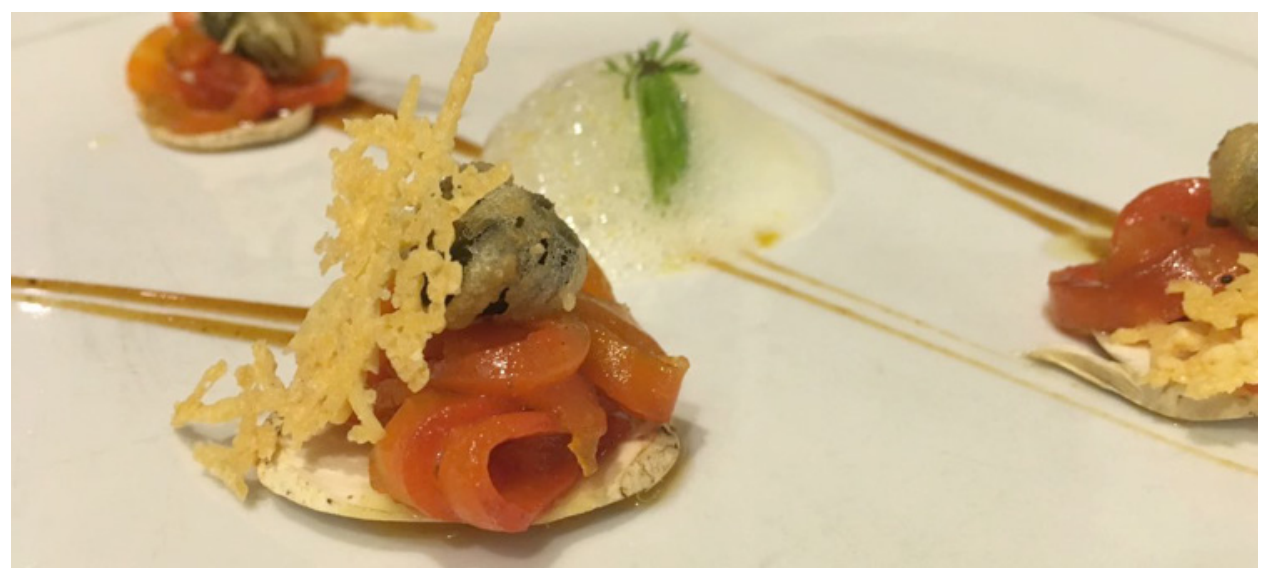


Manuela Romo, Profesora de la Facultad de psicología de la Universidad Autónoma de Madrid y experta en el campo relacionado con la creatividad ligada a la psicología, asegura que la creatividad concierne a la forma de pensar revolucionada de la persona; "creatividad es una forma de pensar cuyo resultado son cosas que tienen, a la vez, novedad y valor. Esa forma de pensar ha sido la responsable, a lo largo de nuestra evolución como especie, del planteamiento de cuestiones relevantes para nuestra supervivencia y desarrollo en la ciencia y la tecnología o para el autoconocimiento en otras formas de conocer." (Ortega)

La creatividad como la innovación, relacionan echos entre si dentro de un proceso creativo, ligado previamente por un metodo para llegar al objetivo deseado por el productor, estas acciones creativas deben responder a las necesidades sociales dentro del entorno que el autor-creador se este desarrollando, es pertinente aclarar que las creaciones sin rumbo como previamente mencione, de forma arbitraria, son productos que probablemente no sean adaptados en un marco cultural y social.

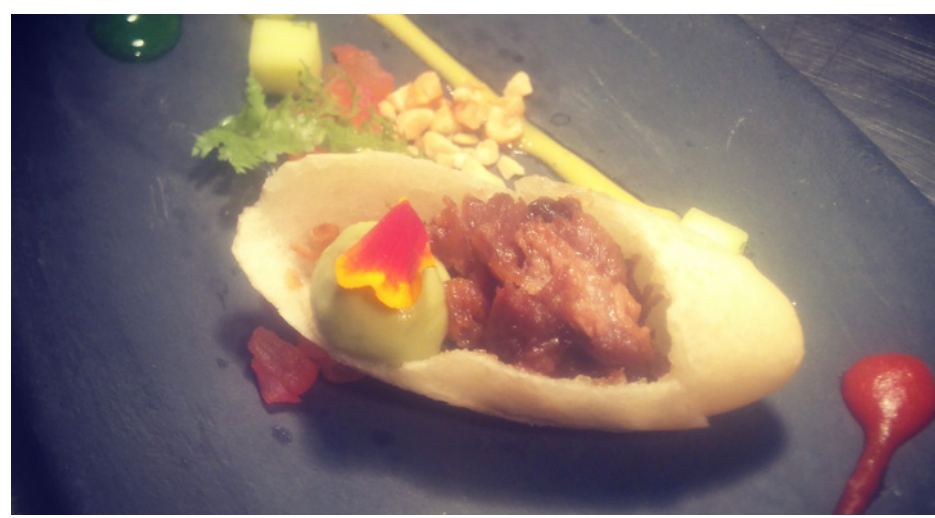

"La creatividad e innovación van de la mano a la inspiración pura del ser humano, pero es importante resaltar la inspiración del artista al momento de

$$
\text { crear." }
$$

\section{"Es el preciso instante donde una idea pasa al plano del desarrollo en físico"}
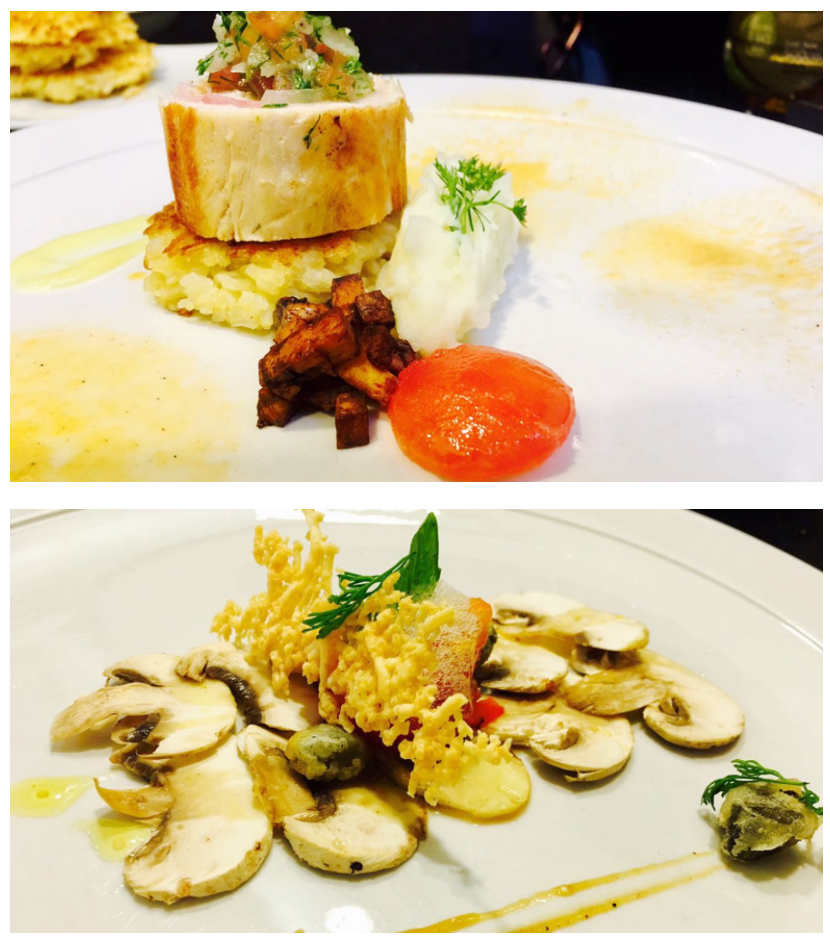

La gastronomia permite un espacio de inspiración, las acciones creadoras son cada vez mas proliferas a medida que pasa el tiempo, pero pocos artistas se detienen en el echo de crear con sentido, solo es crear e innovar por hacer, no por nutrir y explorar; una creacion gastronómica debe satisfacer al cien porciento, al artista y consumidor. Es pertinente demostrar que para crear en un espacio gastronómico, hay que dejar atrás las acciones sin fundamentos; para llevar a cabo un proceso creativo dentro de la gastronomía, hay que tener en cuenta la ciencia como herramienta, el estudio de productos, técnicas y utensilios que sirven como base para que la inspiración fluya de acuerdo a las experiencias vividas y al contacto emocional que el ser humano ha sufrido conforme al vivir del día a día. 